zowych; z nich po złupieniu przez wojska babilońskiego króla zostały w gruzach tylko oczy z kamienia wykonane. Jak w każdym większym mieście Mezopotamii wznosiła się wieża tzw. ziggurat ponad wszystkie budowle, tak i Mari miało swoją ziggurat; najwyższy punkt tell'u przed jego odgrzebaniem, wynoszacy $14,55 \mathrm{~m}$ pokrywał właśnie resztki tej wieży ${ }^{97}$ ).

Dokładny obraz kultury i życia mieszkańców miasta Mari otrzymamy dopiero, skoro muzeum w Luwrze opublikuje wszystkie teksty uzyskane $\mathrm{z}$ wykopalisk.

Katowice

Ks. JÓZEF JELITO

\title{
ROLA TRADYCJI W POWSTAWANIU PENTATEUCHU
}

Jak w Nowym Testamencie do najbardziej roztrząsanych zagadnień należy problem powstania Ewangelii synoptycznych, tak znów w Starym Testamencie takim nie mniej szeroko roztrząsanym zagadnieniem jest problem powstania Pięcioksieggu. Z jednej bowiem strony liczne teksty mieszczące się w księgach biblijnych obu Testamentów ${ }^{1}$ ) wraz z cała Tradycją zarówno żydowską ${ }^{2}$ ), jak i chrzescijańską $\left.{ }^{3}\right)$ świadczyć się zdają, iż Pięcioksiąg jest dziełem Mojżeszowym. Z drugiej strony Pięcioksiagg, wzięty pod szkła nowoczesnej krytyki, zda się temu przeczyć, domagając się raczej powolnego powstawania w ciagu stuleci. Byłby to raczej utwór nie mający nic wspólnego z Miojżeszem ${ }^{4}$ ) albo co najwyżej bardzo mało ${ }^{5}$ ).

${ }^{97)}$ Syria 1939 , t. 20 , str. 4.

1) Mojż. 17,14; 24,4; 34,27; 4 Mojż. 31, 19,22; Joz. 1,7; 3, 3,30; 23,6; 24,26; 1 Król. 2,3; 2 Król. 22,1; Ezdr. 7.14; Jer. 2,8; 18,18; 26,4-5; Dan. 9,10 itd. W N. Test. np. Mk 12,26; Ek 2,22 a szczególnie Jan 5, 45-47 itp.

2) Ant. Jud. 4, 8,48.

3) Zob. E. Mangenot art. Pentateuque w Dict. de la Bibl. V 1912, col. 73-75.

${ }^{4}$ ) Tak utrzymywali zwolennicy tzw. hipotezy uzupełnień, a szczególniej zwolennicy tzw. nowej hipotezy źródeł z głównym jej propagatorem na czele J. Wellhausenem, który pojmował Pięcioksiąg jako dzieło złożone z 4 głównych źródeł J, E. D, P pochodzących z czasów pomojżeszowych. Por. Robert-Tricot, Initiation biblique, Paris 1948, 93.

$\left.{ }^{5}\right)$ Takie było zapatrywanie najstarszych krytyków Pięcioksiegu jak tzw. zwolenników starej szkoły (Astruc-Einhorn), oraz hipotezy fragmentów, której twórca A. Geddes mniemał, iż Pięcioksiąg jest zbiorem różnych fragmentów, z których przynajmniej niektóre sa pochodzenia Mojżeszowego. Zob. Ks. J. Archutowski, Wstẹp do ksiąg St. Test. Kraków 1927, 20-24. 
Nie brakowało też takich uczonych, którzy starali się stworzyć pomost, który by wypełnił przepaść oddzielającą owe dwa powyższe zapatrywania na genezę Pięcioksięgu. Jedni ${ }^{6}$ ), jak z protestantów Klostermann, Dachse, Eerdmans, Wieder, Löhr, Volz, Rudolf itp., a z katolików Hoberg, Zschokke-Döller, Kugler, Hummelauer, Murillo, Bea itp. starali się zmniejszyć trudności wysuwane przeciw pochodzeniu Pięcioksięgu od Mojżesza. Inni ${ }^{8}$ ), że wspomnimy tylko katolików, jak Hügel, Lagrange, Vetter, Nikel, Šanda, Heinisch, Junker, Göttsberger, Stoderl, Ricciotti, choć przyjmowali pochodzenie pewnych części Pięcioksięgu od Mojżesza, to jednak innym jego częściom większym czy mniejszym przypisywali pomojżeszowe pochodzenie od różnych, bliżej nam nieznanych autorów.

Jedna jest jeszcze możliwość, na którą nie zwrócili należytej uwagi katoliccy uczeni przy swych studiach nad genezą Pięcioksięgu, a mianowicie uwzględnienie roli tradycji ustnej, jaką niechybnie odegrała ona w tworzeniu się Pięcioksięgu. Katoliccy badacze ulegając w biblistyce większemu, czy mniejszemu wpływowi protestantyzmu, nie uwzględnili za ich przykładem roli tradycji.

Dopiero na tradycję zwróciła uwagę powstała w ostatnich czasach szkoła form (Gattungsforschung), rekrutująca się z takich protestantów, jak Gunkel ${ }^{9}$ ), Mowinckel ${ }^{10}$ ), Sellin ${ }^{11}$ ) i inni ${ }^{12}$ ), którzy w swych badaniach nad powstawaniem ksiąg biblijnych w przeciwieństwie do dawniejszej krytyki biblijnej rozróżniającej w Piśmie św. wielkie dokumenty, z których ono miało być rzekomo zło-

$\left.{ }^{6}\right)$ Robert-Tricot, Dz. cyt. 84.

`) Heinisch, Das Buch Genesis, Bonn 1930, 61-65.

s) Heinisch, dz. cyt. $64 \mathrm{nn}$. oraz Robert-Tricot, dz. cyt. 99-102.

$\left.{ }^{9}\right)$ Zob. art. Die Grundprobleme der isr. Literaturgeschichte w Deutsche Literaturzeitung 1906 (1797-1800; 1861-1866). Por. Das Buch Genesis, Tübingen 1901.

10) Zob. art. Oppkomsten avprofitliteraturen w Norsk teologisk tidskrift 1942 (65-111).

11) Einleitung in das Alte Testament 1933.38: „Die Einzelerzählungen werden schon seit Jahrhunderten in jüdischem Volksmunde mehr oder weniger feste Formen angenommen haben, anderes kann auch schriftlich fixiert gewesen sein".

12) Można tu wspomnieć także Gressmanna (1910-1922), Hempela (1930), Eissfelda (1932), Alta (1934), Jirku (1937). Por Robert-Tricot dz. cyt. 95. 
żone, zwrócili uwage raczej na małe ustępy, by z ich formy literackiej poznać milieu i czas ich powstania. Ksiegi bowiem święte, a więc i Pieccioksiąg miały być konglomeratem tradycji, stąd jeden z uczonych proponuje nazwać ten nowy kierunek szkołą »historyczno-tradycyjną《 (Cullmann).

Tradycje te jednak nie pochodza od tych osób, jakim je w oparciu o źródła biblijne przypisujemy, ale od różnych społeczności. W społeczności bowiem ma drzemać rzekomo pęd życiowy do tworzenia tradycji, pęd żywy zwłaszcza w cieniu różnych sanktuariów, k.tórym to tradycjom nadaje ów pęd różne formy, już to autochtoniczne, już to zapożyczone z różnych środowisk. Małe tedy ustępy biblijne nie są tworem pisarza, ale sa rzekomo wynikiem nieosobowym społeczeństwa. Forma tych ustępów ma rzekomo zdradzać okoliczności, sytuację, w jakich owe ustępy powstały wśród pewnej grupy ludzi o odpowiedniej wspólności życiowej. Każda tedy forma ma swój, jak to określaja zwolennicy tej szkoły, „Sitz im Leben“. Zibadanie tedy form tych ustępów jest rzekomo zbadaniem powstania tradycyjnych ustępów ${ }^{13}$ ). Forma bowiem i treść są od siebie zależne. Jeżeli tedy idzie o genezę Pięcioksięgu, to nie można móvić o autorze piszącym na podstawie źródeł czy autopsji, ale co najwyżej o zbieraczu istniejących już tradycji.

Według innych uczonych, jak H. S. Nyberg ${ }^{15}$ ), społeczność sama miała być zbieraczem tych $z$ początku luźno wiązanych ze sobą ustępów biblijnych, gdyż dopiero gdzieś po niewoli babilońskiej poczęto na piśmie utrwalać treść tych opowiadań. Mieli w tym względzie Izraelici być naśladowcami innych Semitów.

Nie zamierzamy poddawać szczegółowej analizie powyższego twierdzenia krytyków, tu tylko tyle na marginesie interesującej nas kwestii chcemy zauważyć, iż powyższe twierdzenia są sprzeczne z zasadami zdrowej krytyki historycznej. Szkoła owa bowiem, nie mogąc w sposób naturalny wyjaśnić powstanie religijnej tradycji Pięcioksięgu o treści transcendentnej przez pochodzenie jej od człowieka jednego, gdyż to równałoby się uznaniu owego człowieka za nad-

$\left.{ }^{13}\right)$ Por. M. Dibelius. Die Formengeschichte des Evangeliuns, Tübingen, 1919; K. L. Schmidt, Die Rahmen der Geschichte Jesu, Berlin 1919; R. Bultman, Die Synoptischen Streitgespräche, Berlin 1921; G. Bertram, Die Leidensgeschichte und der Christuskult, Göttingen 1922, itp.

${ }^{14}$ ) Studien zum Hoseabuche, Upsala 1935.

15) Zum hebräischen Traditionswesen (Die Komposition der prophetischen Bücher des Alt. Test). Oslo 1938. 
zwyczajny instrument w ręku Boga, przerzuca ów problem bezpodstawnie na całe społeczeństwo. To zaś z natury swej jest bardziej niezdolne do wytworzenia takiej tradycji. W myśl bowiem zasady, iż „mens agitat molem“ należy raczej przyjąć za zjawisko stwierdzone obserwacją i historią, że wielkie idee, które przenikają masę, są raczej płodem jakiejś wybitniejszej jednostki, która je masie naızuciła. Konkretnie się wyrażając, trzeba zaznaczyć, iż jak nie można odciąć racjonalnie i zupełnie chrześcijaństwa od Chrystusa, tak też nie można odciąć zupełnie i rozumnie mozaizmu od Mojżesza. Nie można odmówić pochodzenia zasadniczych przynajmniej elementów religii Mojżeszowej od Mojżesza. Do takich zaś zasadniczych elementów mozaizmu należy bezsprzecznie monoteizm, nie spotykana nigdzie poza Izraelem synteza nakazów etycznych, wyrażona krótko w dekalogu, a jeszcze krócej w dwóch przykazaniach miłości Boga i bliźniego, czysty kult obrzędowy Jahwy oraz oczekiwania przyjścia z narodu izraelskiego przyszłego Zbawcy świata.

Nie można też zdaniem naszym iść za krytykami starszymi, którzy hołdując ewolucjonizmowi religijnemu i nie uwzględniając kodeksów etycznych i obrzędowych pozaizraelskich, oraz akcentując zbytnio różnice stylistyczne i literackie w Pięcioksiągu, wyróżniali w nim cztery bloki literackie ułożone w kilka wieków po Mojżeszu przez bliżej nam nieznanych autorów. Odkrywcze prace światowej sławy etnologów, jak W. Schmidta ${ }^{16}$ ), W. Koppers'a ${ }^{17}$ ), czy różnych prehistoryków, jak Krafta ${ }^{18}$ ), czy też historyków religii, jak Erman'a ${ }^{19}$ ), Deimel'a ${ }^{20}$ ) wykazały, że monoteizm nie jest terminus ad quem, ale terminus a quo czyli nie jest kresem, ale początkiem religijnej historii ludzkości. Dociekania tychże ucżonych stwierdziły również, iż z wysoką ideą Bóstwa harmonizuje też odpowiednio wy-soka etyka, oraz odpowiednio czysty kodeks rytualny. Ze znalezionych dokumentów w Ras Szamra, pochodzących z czasów mojżeszowych wiemy, że wiele takich obrzęów i ofiar, o jakich jest mowa w księdze Leviticus, było znanych i taką samą nazwą określanych w owym mieście ${ }^{21}$ ).

$\left.{ }^{16}\right)$ Origine et évolution de la Religion (tł. franc. z niem. przez A. Lemonyer) Paris 1931, 105.

17) Der Urmensch und sein Weltbild, Wien 1949

1s) Der Urmensch als Schöpfer: Die geistige Welt des Eiszeitmenschen, Berlin 1942.

19) Die ägyptische Religion, Berlin 1904.

$\left.{ }^{20}\right)$ Panteon Babylonicum, Romae 1912.

^1) Ks. E. Dąbrowski, Studia biblijne, Warszawa 1951, 23-35. 
Nie można też dziś utrzymywać, jak to czyni Nyberg czy Birkenland, że dopiero po niewoli babilońskiej zaczęto spisywać ustnie clotąd przekazywaną treść Pięcioksięgu, gdyż temu apriorystycznemu twierdzeniu przeczą przeliczne teksty biblijne i to nawet znajdujące się w takich księgach, które powstały gdzieś zaraz po niewoli, a więc wtedy, kiedy rzekomo poczęto spisywać Pięcioksiąg. Szukanie zaś przez owych uczonych analogii u innych narodów wyjdzie tylko na korzyść tradycyjnego zapatrywania pod warunkiem, że.czynione jest beztendencyjnie, sprawiedliwie. Literatura bowiem religijna znana była na liczne wieki przed Mojżeszem w Egipcie czy Babilonii. Toteż ustne nauczanie Izraelitów przez Mojżesza w ciągu 40 lat kierowania nimi na pustyni mogło być spisane dla utrwalenia tej jego nauki.

Czy jednak ta nauka była spisana przez jednego czy też przez kilku pisarzy? $\mathrm{Z}$ różnic stylowych występujących zarówno w historycznych częściach Pięcioksięgu jak i prawniczych należy raczej przyjąc dwu autorów spisujących historię, a dwu autorów kodyfikujących prawa, a ponadto, oprócz owych 4 bloków wyróżnionych w Pięcioksięgu z racji stylistycznych, należy też wyróżnić jeszcze cały szereg mniejszych ustępów nie dających się zamknąc w owych 4 blokach mających swój swoisty styl. Noszą one stylowo i treściowo znamiona pomojżeszowego pochodzenia.

Zachodzi teraz pytanie, czy Mojżesz posiadający bezsprzecznie sz.tukę pisania (por. 2 Mojż. 2,5, 5,15; Dz. Ap. 7,22) był autorem jednego z owych bloków? Z racji licznych zajęć Mojżesza, jakie wynikały z jego powołania, raczej trzeba tylko przyjąc, że powstałą w nim inicjatywę spisania swego nauczania powierzył do wykonania kronikarzom, wybranym z Izraelitów, z których wielu posiadało niewątpliwie sztuke pisania. Przecież w owym czasie is ${ }^{\dagger}$ nieli także kronikarze przy boku faraonów egipskich czy królów babilońskich, spisujący , ważniejsze czyny i prawa swych władców. Mojżesz, znający owych kronikarzy, mógł ich instytucję erygować przy swoim boku - tym więcej, że za życia jego dokonywały się tak wielkie rzeczy nie tylko ważne dla własnego narodu, ale i dla całej ludzkości. Byli tacy kronikarze znani w Izraelu w czasach królewskich, ich kronika była głównym źródłem dla autora ksiąg królewskich, na które ciągle się powołuje. Jednym z takich kronikarzy byłby ów pisarz ,Jahwista“, który pospisywał początki ludzkości (1 Mojż., 2, 4b-11, 32), powołanie Abrahama, jego dzieje, jak i dzieje Izaaka, 
Jakuba (1Mojż. 12, 1-25, 18), oraz częściowo historię Józefa (1 Mojż. 25-36), oraz tzw. dekalog jahwistyczny. Opisał te fakty barwnie z. wielkim dynamizmem, starając się zapewne o wierne odtworzenie dynamizmu mów Mojżesza. Zachował nam ów kronikarz kunszt tych mów oraz gorącą duszę Mojżesza. Boga nazywa on głównie :,Jahwe“, dlatego możemy za krytykami nazwać owego anonimowego kronikarza ,Jahwistą“. Drugi kronikarz — nazwijmy go „Elohistą“opisał już to nowe, już to te same szczegóły o patriarchach. Ma ta kronika opowiadania własne: pobyt Abrahama w Gerarze (1 Mojż. 20), ofiarowanie Izaaka, jak też pewne opowiadania z życia Józefa (i Mojż. 41,42,45), czy téz opowiadania o zwycięstwie nad Amalecytami (2 Mojż. 17), przybycie Jitra do obozu (2 Mojż. 18), złoty cielec (2 Mojż. 32), szemranie Marii i Aarona (4 Mojojz. 22) i przepowiednie Balaama (4 Mojż. 23). Ma fragmenty poetyckie (2 Mojż. 15,21; 17,6; 4 Mojż. 10,35; 21,14-29; 23,7-24). Ma téz niektóre prawa, jak kodeks Przymierza (2 Mojż. 20,23-23, 19). Autor tej kroniki jest znakomitym psychologiem, malującym trafnie stany duchowe swych bohaterów.

Innym kronikarzem byłby któryś z doradców Mojżesza, któremu Mojżesz oddał sądowniczą władzę. Ten pospisywał owe prawa, które krytyka przypisuje Deuteronomiście; z tym zastrzeżeniem, iż wielu praw jeszcze tam nie było, które zawiera wyróżnione przez krytyków źródło D. Zawierał ów kodeks prawa etyczne, cywilne, karne. Komuś wreszcie $z$ kapłanów polecił spisać ustanowione przez siebie prawo rytualne, tyczące się kultu, świąt, miejsca kultu,' podział Transjordanii itp.

Następnie dał Mojżesz owe 4 kroniki kapłanom i polecił je ich opiece i straży. Uchodziły one w opinii Izraelitów za spuściznę Mojżeszową i razem z jego imieniem i żywymi wciąż wspomnieniami ustnymi o Mojżeszu należały do najcenniejszych skarbów religijnonarodowych. Im to uczucie religijno-narodowe było żywsze, tym cześć dla tych „Mojżeszowych“ kronik była żywsza. Gdy z czasem wiele wyrazów tych dokumentów było niezrozumiałych, zaczęto je, jak to się dzieje z Wujkową Biblią, unowocześniać. Zabrano się najpierw do unowocześniania tégo dokumentu, który najlepiej oddawał osobę Mojżesza, do dokumentu jahwistycznego. Lagrange ${ }^{22}$ ) przypuszcza, iż styl tego dokumentu pokrywa się z stylem 2 Sam.

22) Rev. Bibl. 1938, 176-183. 
9-20, czyli ten sam kronikarz mógł był go modernizować, który spisywał ówczesne rządy króla Dawida, opisane w tych rozdziałach. Nie będziemy dalecy od prawdy utrzymujac, że kronikarz ów rekrutujący się zapewne z pokolenia kaplańskiego, w pracy tej się radził króla Dawida. $Z$ jego polecenia niejeden ważny szczegół, który był znany tylko z ustnego opowiadania, został dodany do owego zmodernizowanego dokumentu. Wielki zaś czciciel Mojżesza F.liasz (zob. 1 Król. 19,1-21) lub któryś z innych proroków działających w królestwie północnym, gdzieś w IX wieku, jak na to zdaniem Lagrange'a wskazują racje stylowe, unowocześnił drugi dokument o Mojżeszu, zwany elohistycznym, a równocześnie uzupełnił go tradycjami ustnymi, jakie żywe były w tym królestwie. Po upadku królestwa północnego (i22) gorliwy o święte księgi król judzki Ezechiasz (721--693), o ktćrym mówi Pismo św., że pozbierał przypowieści Salomona (Przyp. 25,1), zreformował lewitów, polecając im chwalić Jahwę pieśniami Dawida i Asafa (2 Kron. 32,27-29), por. 2. Król. 20,13; Iz. 39,2) i który sam układał natchnione pieśni (Iz. 3\&,9-20), kazał połączyć to dzieło elohistyczne z dokumentem jahwistycznym.

Tenże sam król nakazał kapłanom i uczonym przejrzeć dokument D z prawami Mojżesza i dołączyć doń wszystkie prawa, jakie w ciągu wieków na podstawie tychże praw wydano, zarówno w królestwie judzkim jak i izraelskim. Wczesna śmierć nie pozwoliła temu królowi na ogłoszenie owego dzieła. Ukryte w świątyni przetrwało tam prześladowanie Manassesa (693-639) i Amona (639-638). W ciągu tak długiego czasu prześladowania być może, iż zapomniano o nim, toteż słusznie można mówić o jego odkryciu za czasów Jozjasza przy restauracji świątyni w 622 roku przez arcykapłana Helcjasza. W całym tym dokumencie wprawdzie Mojżesz przedstawiony jest jako jedyny prawodawca, ale może to być pewnego rodzaju przesada literacka, aby zaznaczyć, iż znajdujące się tam prawa podstawowe, że Izrael jako lud Jahwy winien być święty; miłować 3oga i wszystkich ludzi, jako siebie samego, są prawami Mojżeszowymi rozwiniętymi przez proroków i kapłanów.

Kiedy upadło także królestwo judzkie (587) i kiedy razem z upadjriem tego państwa znikł kult Jahwy z powodu zburzenia świątyni jerozolimskiej, a kapłani dostali się do niewoli babilońskiej, wówczas gorliwi patrioci z inicjatywy proroka Ezechiela postanowili zmodernizować ostatni dokument spuścizny Mojżeszowej - rytuał obrzę- 
dowy. Dotąd potrzeby tej modernizacji nie odczuwano, nie było téz potrzeby wpisywania do tego dokumentu licznych ustnie przekazywanych przepisów rytualnych, gdyż dynastyczne kapłaństwo lewickie znało praktycznie nie tỷlko ów spisany rytuał, ale też wszystkie inne prawa tego rodzaju ustnie dotąd przekazywane, tak te, które miały pochodzić od Mojżesza, jak i te, które jako nowele wydano w czasach pomojżeszowych. Ale obecnie lękano się, by przez brak praktyki nie poszedł w zapomnienie ów rytuał i dla tego go zmodernizowano i uzupełniono tym wszystkim, co odnosiło się do kultu, względnie ów kult usprawiedliwiało (np. 1 Mojż. 1,1-2,2). Ezdrasz po powrocie swym do Palestyny ogłosił ten kodeks (Neh 7,73), aby kapłani według jego przepisów odbywali liturgię w nowoodbudowanej świątyni. Ponadto Ezdrasz połączył ów rytuał z innymi już razem złączonymi dziełami, zawierającymi nauke Mojżesza.

Taka koncepcja powstania Pięcioksięgu zadość czyni przekonaniu tylowiekowemu tak żydów, jak i chrześcijan, co więcej samych cuutorów ksiag biblijnych obu Testamentów, oraz wypowiedzi sainego Chrystusa, gdyż Mojżesza stawia jako inicjatora spisania głoszonej przez niego nauki. Czyni też zadość i racjom krytyków, wyjaśniając podnoszone przez nich - zresztą słusznie ${ }^{23}$ ) — różnice stylowe $w$ poszczególnych częściach Pięcioksięgu. Koncę̣cja powyższa zgodnie z ekonomia Bożą w N. Test., która niechybnie podobną była do ekonomii Bożej w Starym Testamencie, podkreśla rolę tradycji ustnej w genezie Pięcioksięgu. Pięcioksiąg wtedy to rzeka wytrysła ze źródeł tradycji ustnej. Jak zaś źródło jest wcześniejsze od rzeki, jak rzekę wciąż zasila, tak było też z Pięcioksięgiem; jest on niby rzeka późniejszy od tradycji i wciąż przez nia zasilany.

\section{II.}

Zachodzi z kolei pytanie, czy owa ustna tradycja, na którą się tyle powołujemy, zasługuje na wiarę czyli czy nam z taką wiernością przekazała naukę Mojżeszowa względnie przedmojżeszową, jak ja zachowały dokumenty Mojżeszowych sekretarzy. Zachodzi pytanie, czy ów ustny sposób przekazywania wiadomości o wydarzeniach i prawach był podległy zmianom, jak to się dzieje dzisiaj z opowiadaniami o pewnych osobach czy zdarzaniach, czy też cieszył

$\left.{ }^{23}\right)$ E. Aman, art. w Dict. de Théol. cath., s. v. Pentateuque t. 12, col. 1181. 
się taką samą stałością, jaka cieszy się dzisiejsza tradycja religijna w koncepcji katoliclziej.

$\mathrm{Na}$ powyższe pytanie stara się nam dać odpowiedź nie tylko Biblia, ale té̇ dzisiejsza nauka.

Ta ostatnia, badajac współczesne ludy dzikie, konstatuje rozproszone wśród nich te opowiadania, które stanowia treść prehistorii biblijnej (1Mojż. 1-11). Sa to ludy najbardziej prymitywne, które z niewytłumaczonych powodów odznaczają się wielkim konserwatyzmem form materialnej i społecznej kultury. Można z tego konserwatyzmu wnioskować, iż najwierniej zachowały też te ludy tradycje, jakie ożywiały ludzkość według opowiadania początkowych rozdziałów Genesis. Tacy uczeni, jak Dhorme czy Vaux, a ostatnio Chaine wykazali zgodność z danymi historyøznymi opowiadań Geresis o patriarchach ${ }^{24}$ ). Szczególniej tę zgodność wykazał znany archeolog Albright ${ }^{25}$ ). Odrzuca on usiłowania krytyków, pragnących określić owe opowiadania o patriarchach biblijnych jako etiologiczne legendy, mające za cel wyjaśnienie ludowe nazw różnych miejscowości. Zdaniem tego uczonego takie tłumaczenie jest przesadą, jeśli bowiem ludowa wyobraźnia zajęła się pewnymi miejscowościami, to musiało tam się zdarzyć coś nadzwyczajnego. Ciekawość bowiem wytłumaczenia nazwy jakiejś miejscowości jest wynikiem pewnych faktów uprzednich. Nie można tedy utrzymywać a priori, że legendy etiologiczne tworzyły dopiero swój przedmiot. Na dowód zaś wierności w przekazywaniu ustnej tradycji powołuje się Albright na treść Iliady. Wypadki w niej rozegrane sięgają końca okresu myceńskiego (1180 zdobycie Troji). W tym okresie Grecy nie posiadali pisma, alfabet bowiem fenicki przyjęli dopiero pod koniec 8 wieku. Treść Iliady przekazywali ustnie aż do 7 wieku, kiedy to powstały pierwsze fragmentarycznie spisane ustępy tego utworu i aż do 6 wieku, kiedy to ostatecznie ujęto pisemnie całą treść Iliady. Przèchowali zaś ową treść wiernie, gdyż Miada mimo spisania jej w 6 wieku jest obrazem cywilizacji myceńskiej. Tak kultura myceńska zachowała się w opisie budowy domu, broni oraz w spasobie prowadzenia wojny. Przekazała nam téz warunki międzynarodowe, jakie zapanowały w Azji po upadku

24) Zob. J. Chaine, Le livre de la Genèse, Paris 1948, 220.

25) The Archeology of Palestine and the Bible, Baltimore, 1934, 184 por. From the Stone Age to Christianity, Baltimore, 1946, 33-42. 
państwa hetyckiego i jakie były przed najazdem Dorów i kolonizacją grecką. Tradycja tedy okazała się tutaj gwarantką autentyczności nie mniej wierną jak pismo. A co ważniejsza, choć później spisano Iliadę, to ją interpolowano, jak interpolowało średniowiecze epopeje Nibelungów czy pieśń o Rolandzie ${ }^{26}$ ).

I dziś u wielu szczepów istniejąca tradycja o przeszłości narodowej jest znakomitym środkiem do przekazywania potomnym z. wielką wiernością najdrobniejszych szczegółów tej przeszłości. IyIusil ${ }^{27}$ ), opisując zwyczaje dzisiejszych beduinów arabskich, nadmienia, iż przy ognisku słuchają z wielką uwaga opowiadań o genealogii, o historii pokolenia, po tysiąckroć i gdyby recytator pomylił się, to natychmiast go poprawiają. Wszyscy tedy znają na pamięć historię pokolenia czy rodziny. Przy ognisku recytują też opowiadania poetyckie czy epickie. Niekiedy recytacje te są dość aługie. Nigdy poeci nie układają ich od razu. Raz ułożą parę wierszy dla swych czy obcych dzieci, to znów im dalsze wiersze podają. Liczne recenzje tego samego utworu są uznawane przez poetę jako pochodzące od niego.

F. Ashkenazi ${ }^{28}$ ), opisując życie dzisiejszych półkoczowniczych plemion palestyńskich, wspomina o deklamatorach recytujących różne poematy, genealogie i historie pokolenia. Są powszechnie szanowani, gdyż dzięki nim historia pokolenia trwa.

Pamięć ludzka ma granice, dlatego dłuższe utwory utrwalono na piśmie, przynajmniej podstawowe i ważniejsze ich części. Drerupp ${ }^{29}$ ) utrzymuje, iż niektórzy recytatorzy zdołali przechować w pamięci - do 15.000 wierszy należących do różnych utworów, jeślj zaś chodzi o śpiewaków serbskich to od 30.000-70.000 wierszy, lecz zdaje się, iż ci nie od razu deklamowali całość. Muzułmanie dość często umieją dziś Koran na pamięć, stanowiący 70\% Nowego Testamentu. Św. Hieronim pisze, iż Orygenes miał umieć całe Pismo św. na pamięć ${ }^{30}$ ). Powszechnie wiadomym jest, iż angielski poeta IMilton swój słynny utwór „Paradise Lost“, liczący 12.000 wierszy,

${ }^{26)}$ E. Drerupp, Das Homerusproblem in der Gegenwart, Würzburg $1921,326$.

${ }^{27}$ ) Arabia Petrea, III.

28) Tribus semi-nomades de la Palestine du Norá, Paris, 1938, 98.

$\left.{ }^{29}\right)$ Dz. cyt. 260.

${ }^{30}$ ) Ep. 98,8 . 
ułożył będąc ślepym, dyktując go swej żonie względnie jednej z dwu córek.

Dziś nauka skonstatowała, że ludy posiadają liczne sposoby dla ułatwienia sobie wiernego przekazywania tradycji. Do takich środków należy: poezja, formuły typowe, paralelizmy, antytezy, które wbijają się w pamięci i dopomagają do wiernego przechowania ustnych podań ${ }^{31}$ ).

Powyższe przykłady pozabiblijne stanowią paralele do opowiadań biblijnych w ogólności, w szczególności zaś do treści Pięcioksięgu całego, a zwłaszcza księgi Genesis. Choć opisy biblijne w tych księgach mogą nosić na sobie pewne cechy pochodzenia od redaktora, to jednak w całości sa wiernym odbiciem opisywanej epoki. Nie są one tworem wyobraźni, gdyż tętnią życiem, epoką i kolorytem lokalnym. Również imiona wskazują na historyczność owych opisów. Imię Abrahama jest spotykane w dokumentach mezopotamskich, zaś imiona Izaak, Jakub są imionami amorejskimi, rzadko spotykanymi u Izraelitów przed Dawidem. Także znamiennym jest, iż w okresie patriarchów sławne są takie miasta jak Betel, Hebron, Eersabe; gdyby to był wytwór legendarny tradycji, którejby nie odpowiadała rzeczywistość, to by były sławne inne miasta, jakimi były w okresie recenzji tychże opowiadań: Silo, Gabaon, Gilgal, Mispa, Jeruzalem itp. Toteż słusznie tak konkluduje wspomniany Chaine swoje rozważania o historyczności księgi Genesis: „Iż opowiadania te zawieraja stare pamiątki osób realnych i choć nawet nie zasługuja na miano historii w dzisiejszym słowa znaczeniu, to niemniej są one cennym zabytkiem do poznania początków Izraela i jego objawienia“" ${ }^{2}$ ).

Tak ujęte powstanie Pięcioksięgu w Starym Testamencie z uwzględnieniem niezwykłej roli tradycji, jaką w genezie tego dzieła ona odegrała, harmonizuje do pewnego stopnia z powstaniem 4 Ewangelii kanonicznych w Nowym Testamencie, których również tradycja była źródłem i wierną towarzyszką. Ponadto podkreślenie tradycji w powstaniu Pięcioksięgu ujawnia nam lepiej wszechmoc i mądrość Bożą, która swe objawienie przekazała nam nie tylko przez martwe litery pisma, ale też przez żywe słowa tradycji. Nie jest zaś to ujęcie sprzeczne ani $z$ tekstami biblijnymi, ani też $\mathrm{z}$ od-

$\left.{ }^{21}\right)$ Por. MI. Jouse, Le style oral mnémotechnique chez les Viarbomoteurs, Paris, 1925.

$\left.{ }^{32}\right)$ Por. J. Chaine, Dz. cyt. 457. 
nośnymi orzeczeniami Komisji Bibilinej, tak z 28. VI. 1906, gdzie jest powiedziane, iż Mojżesz mógi posłużyć się sekretarzami ${ }^{33}$ ), ani też z ostatnia enuncjacją Komisji Biblijnej do kard. Suharda z dnia 16. I. 1943, gdzie wyraźnie jest powiedziane, iż „nie ma dziś nikogo, kto by poddawał w watpliwość istnienie źródeł, jak też nie przyjmował stopniowego narastania praw Mojżeszowych, spowodowanych warunkami społecznymi, religijnymi, czasów późniejszych. Riozwój ten widoczny jest też W opowiadaniach historycznych" ${ }^{34}$ ).

Tarnów

K. STANISEAW ŁACH

\section{ZNACZENIE I SENS MESJAÑSKI KUSZENIA CHRYSTUSA}

Z dziejów ziemskiego życia Pana Jezusa uderza dziwnie czytającego Ewangelie synoptyczne opowiadanie o kuszeniu Chrystusa. Narzuca się tu szczególnie naszej uwadze fakt, że Syn Boży poddał sie poduszczeniom szatana. Na skutek bardzo szczupłej i fragmentarycznej relacji synoptyków ${ }^{1}$ ) o tym tajemniczym zdarzeniu, natura kuszenia, sposób walki Chrystusa z szatanem, jest niejasny i sprawia wiele trudności, gdy chcemy zbadać jej szczegóły. Opinie egzegetów są podzielone: Ojcowie Kościoła i dawniejsi tłumacze przyjmują zewnętrzny charakter pokus, tzn. zmianę miejsca, ludzką postać szatana, fizyczne przeniesienie lub pieszą wędrówkę Chrystusa. Úczeni nowszych czasów ${ }^{2}$ ) oświadczają się natomiast za wewnętrznym charakterem pokus. Kuszenie według nich byłoby czymś w rodzaju wizji, jakimś sugestywnym oddziaływaniem szatana na zmysły i wyobraźnię Chrystusa Pana ${ }^{3}$ ).

33) Ench. Bibl. 176-177.

${ }^{34}$ ) Tekst podany w RBZ I (1948) s. (126-129). Do całości por. artykul ks. Jakubca pt. „Historyczna tradycja izraelska“ w RBL III (1950) s. 340-350.

1) Mt 4, 1-11; Mk 1, 12-13; Łk 4, 1-11.

2) Le Camus, La vie de N. S. Jésus-Christ, I, Paris, 236-253. - Tobac, Revue d'histoire ecclesiastique XVIII (1922) I, 318-319. - Lebreton, La vie et enseignement de Jésus - Christ, Notre Seigneur, I, 80, notatka w przypisku. Vogels, Die Versuchung Jesu (Bibl. Zeitschrift 17) 253. - Lauck, Matthäus und Markus (Die Heilige Schrift für das Leben arklärt XI) 34.

3) Opinia pojmowania pokus jako wewnętrznej wizji, której wyłącznym sprawcą pozostaje szatan, jest możliwa i dotychczas nie potępiona przez teologię dogmatyczną. Por. Lagrange, Evangile selon saint Matthieu, Paris 1923, 65. 